\title{
A practical approach of salt and protein restriction for CKD patients in Japan
}

\author{
Kunitoshi $\mid$ seki $^{{ }^{*}}$ and Kunihiro Yamagata ${ }^{2,3}$
}

\begin{abstract}
Dietary management, in particular salt and protein restriction is fundamental for the proper care of CKD patients. Therefore, a practical guide to the dietary treatment may be helpful among progressive CKD patients. In Japan, two academic societies such as Japanese Society of Nephrology and Japanese Society for Dialysis Therapy have recently published Guidelines for Dietary Management for non-dialysis dependent CKD and dialysis-dependent CKD, respectively.

In this manuscript, we summarized the practical guide for salt and protein restriction from the Japanese Society of Nephrology to retard the progression of CKD to endstage renal disease. This guide will promote further the collaboration of Nephrologists and Dietitians.
\end{abstract}

\section{Background}

CKD is common and the number of patients on renal replacement therapy (RRT) is estimated more than 330,000 in Japan [1]. It is becoming a social and economic burden. More than half of incident dialysis patients are CKD associated with diabetes mellitus (DM) and hypertension. Early detection and treatment would be necessary to retard the progression of CKD. Therefore, life-style modification including dietary management is important in patients with DM, hypertension, dyslipidemia, obesity, metabolic syndrome, and hyperuricemia. Among the dietary management, salt and protein restriction are critical for CKD patients, however it is influenced by differences in ethnic, regional, and cultural factors. We recently summarized a manual for dietician and other medical staff concerning life-style and dietary management in CKD patients (written in Japanese) [2, 3].

\section{Discussion}

\section{Manual for dietary management}

Table 1 summarized the guidance for lifestyle and dietary modification in CKD patients. Firstly, it is important diagnose the current stage of CKD (eGFR and proteinuria), cause of CKD, and also it is helpful to obtain the recent trend in CKD progression, pattern and slope of eGFR decline. Check the current medication and adherence to the drug therapy. Cessation of smoking and weight control should be accompanied with salt restriction and protein restriction. Until favorable results obtained, several rounds will be needed (Table 2).

\section{Steps for salt and protein restriction}

1. Use the checklist Obtain clinical and laboratory information of the patient.

2. Check the current problem Adherence to drug therapy should be checked. Important categories are body mass index (BMI), blood pressure, fasting blood glucose, LDLcholesterol.

3. Guidance by category Salt $(\mathrm{NaCl})$ Restriction, Protein Restriction

4. Guidance by algorithm BMI, Blood Pressure, Blood Glucose, Lipid, Smoking Cessation, Potassium, Uric Acid

5. Useful materials Salt content in food staff

\footnotetext{
*Correspondence: Chihokun_ohra@yahoo.co.jp

${ }^{1}$ Clinical Research Support Center, Tomishiro Central Hospital, Tomigusuku,

Okinawa, Japan

Full list of author information is available at the end of the article
} 
Table 1 Guidance for Lifestyle and dietary modification in CKD patients (Cited with permission from the Japanese Society of Nephrology)

\begin{tabular}{|c|c|}
\hline \multicolumn{2}{|l|}{ 1. Lifestyle and Dietary Modification } \\
\hline \multicolumn{2}{|l|}{ 2. Weight control: $\mathrm{BMl}<25.0 \mathrm{~kg} / \mathrm{m}^{2}$} \\
\hline $\begin{array}{l}\text { 3. Salt restriction: } \mathrm{NaCl} 3 \text { to } 6 \mathrm{~g} / \text { day } \\
\text { (if hypertensive) }\end{array}$ & $\begin{array}{l}\text { Target blood pressure: } \\
<130 / 80 \mathrm{mmHg}\end{array}$ \\
\hline \multirow{5}{*}{$\begin{array}{l}\text { 4. Protein restriction (Body weight } \\
\text { as body mass index } 22.0 \mathrm{~kg} / \mathrm{m}^{2} \text { ) }\end{array}$} & Stage 3a: 0.8 to $1.0 \mathrm{~g} / \mathrm{kg} / \mathrm{day}$ \\
\hline & Stage 3b: 0.6 to $0.8 \mathrm{~g} / \mathrm{kg} /$ day \\
\hline & Stage 4/5: 0.6 to $0.8 \mathrm{~g} / \mathrm{kg} /$ day \\
\hline & $\begin{array}{l}\text { Stage 5D: HD patient } 0.9 \\
\text { to } 1.2 \mathrm{~g} / \mathrm{kg} / \text { day }\end{array}$ \\
\hline & PD patient 0.9 to $1.2 \mathrm{~g} / \mathrm{kg} /$ day \\
\hline \multirow{2}{*}{$\begin{array}{l}\text { 5. Potassium restriction } \\
\text { (if hyperkalemia) }\end{array}$} & Stage $3 b: \leq 2000 \mathrm{mg} /$ day \\
\hline & Stage 4/5: $\leq 1500 \mathrm{mg} /$ day \\
\hline \multicolumn{2}{|l|}{$\begin{array}{l}\text { 6. Glucose (if DM present): } \\
\mathrm{HbA} 1 \mathrm{c}<7.0 \%\end{array}$} \\
\hline $\begin{array}{l}\text { 7. Lipids (if dyslipidemia): } \\
\text { LDL-C }<120 \mathrm{mg} / \mathrm{dL}\end{array}$ & \\
\hline
\end{tabular}

\section{Salt restriction}

1) Rationale Salt restriction is essential for CKD patients. If not adequately controlled, salt retention may cause edema, heart failure and hypertension. Daily intake from foods and additives should be estimated carefully. In particular, salt intake may vary with cooking process.

2) Practical Guide We summarized several tools to help adhering to salt restriction.

a) Salt content in seasoning (Fig. 1)

Use spoon to estimate the amount of added seasoning, in particular when uses common seasoning materials such as table salt, source, and Miso.
Estimate roughly as salt (gram) per one small spoon. Select low salt seasoning and law salt food staffs (Avoid too much).

Check the salt ingredient in each food staff.

b) Salt content in processed food (Fig. 2)

Processed foods are difficult to check. When expressed as salt content as "mg", salt content should be calculated as: $\mathrm{Na}$ (mg) X 2.54/1000 = Salt (g)

c) Tips for cooking (Fig. 3)

Salt restricted food is often regarded as "nonpalatable". Adherence to salt restriction could be improved by using other seasoning materials without salt. It may take time to adjust salt restriction.

d) Restaurant (Fig. 4) Generally, cooked-food and diet outside home are salt-rich, although it may differ by restaurant or region. It may be helpful to "recall what and how much have eaten, etc." Advice to check the nutrient content when buy the cooked foods.

Some tips;

/Ask low salt cooking at restaurant/Do not drink soup when ordering/

/Use separate dish for dressing or mayonnaise/Select food easy to estimate salt intake/When eat-out, restrict salt more than usual at home

e) Avoid too much salt restriction Too much, less than $3 \mathrm{~g} /$ day, salt restriction is dangerous if adequate food intake has not accompanied.

\section{Protein restriction}

1. Rationale Ingested protein is finally metabolized to water, carbon dioxide, and other compounds, mainly

Table 2 Flow chart for Lifestyle and dietary modification (Cited with permission from the Japanese Society of Nephrology)

\begin{tabular}{|c|c|}
\hline \multirow[t]{3}{*}{$1^{\text {st }}$ Round } & 1) Obtain good rapport with patient \\
\hline & 2) Make a checklist for individual patient \\
\hline & 3) Clear the priority (What is the category in the checklist?) \\
\hline For: Protein restriction, Salt restriction & Use the manual of Guidance (30 min in each guidance) \\
\hline For: Weight control, Hypertension, Hyperglycemia & $\begin{array}{l}\text { Hyperkalemia, Smoking cessation, Hyperlipidemia, Hyperuricemia, } \\
\text { Use algorithm (30 min in each guidance) }\end{array}$ \\
\hline \multirow[t]{3}{*}{$2^{\text {nd }}$ Round: If not satisfactory, repeat the guidance again } & If the first priority was successful, then try second \\
\hline & $\begin{array}{l}\text { 3rd Round: If not satisfactory, repeat the guidance again } \\
\text { (Continue counselling) }\end{array}$ \\
\hline & $\begin{array}{l}\text { If the second priority was not-successful, then repeat } \\
\text { the guidance again }\end{array}$ \\
\hline
\end{tabular}



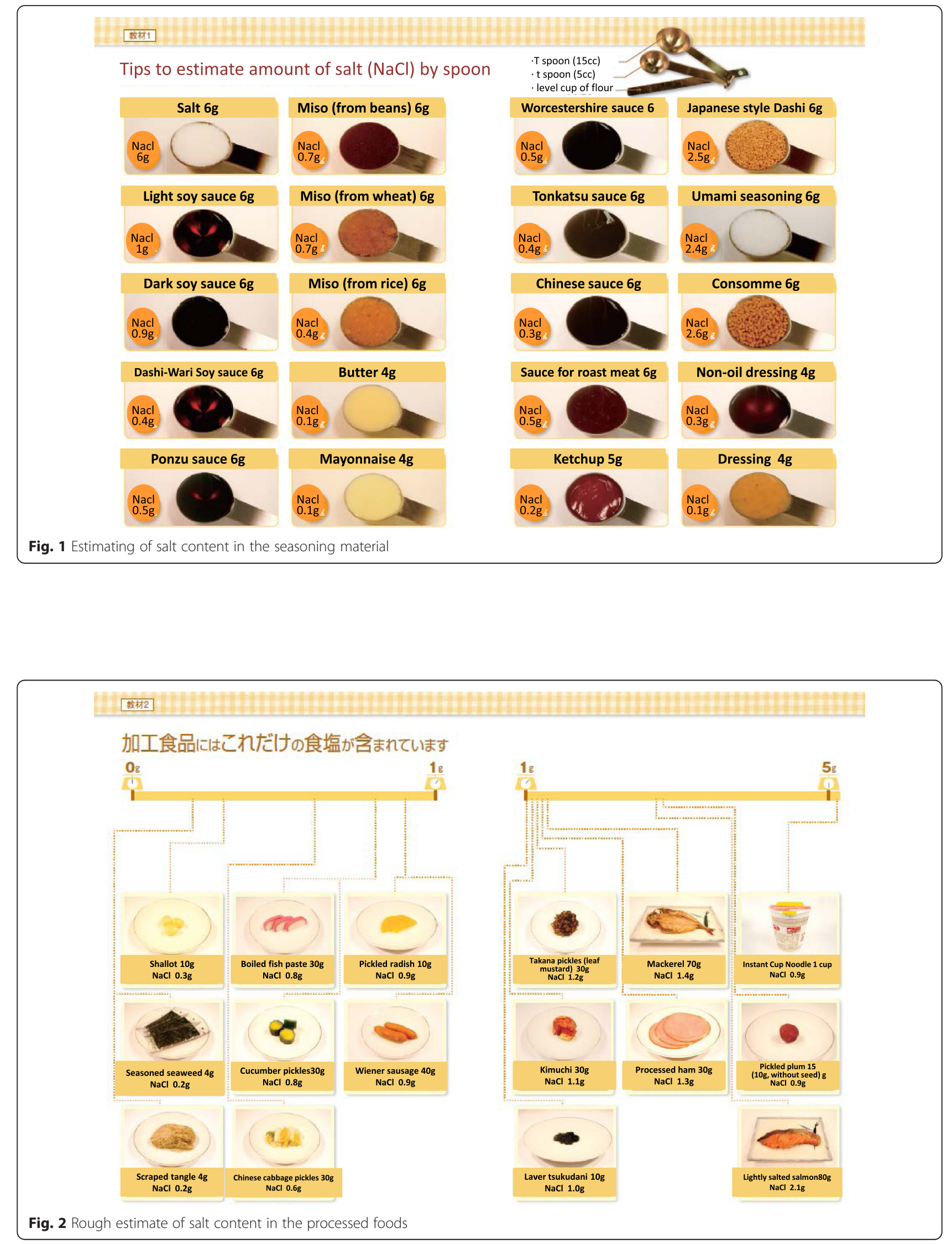


\section{较林 4}

Tips to reduce salt intake

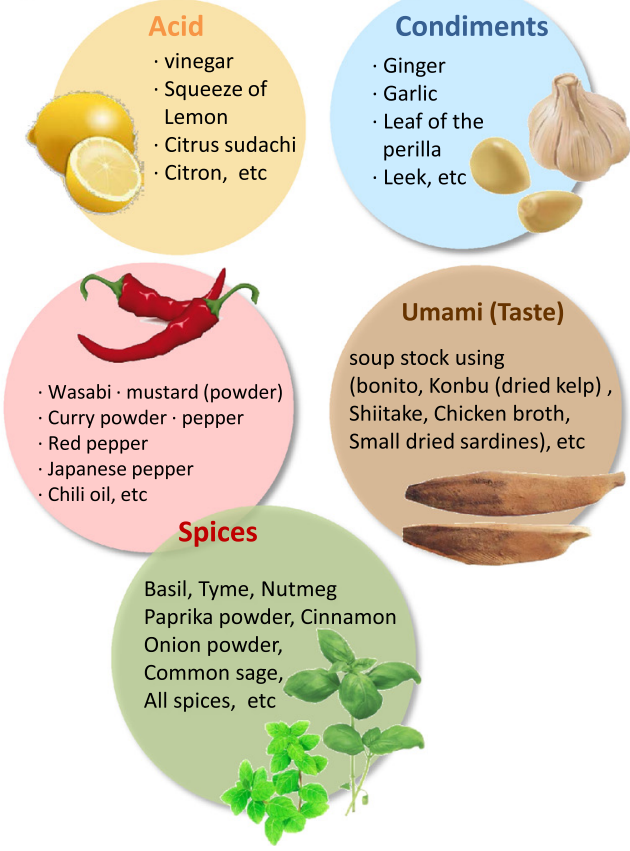

\section{Use Dashi -Wari Soy Sauce}

Dashi-Wari Soy Sauce contains lower Amount of salt than conventional one. It is palatable, good flavor and has lower potassium contents. Dashi denotes Japanese-style soup/broth.

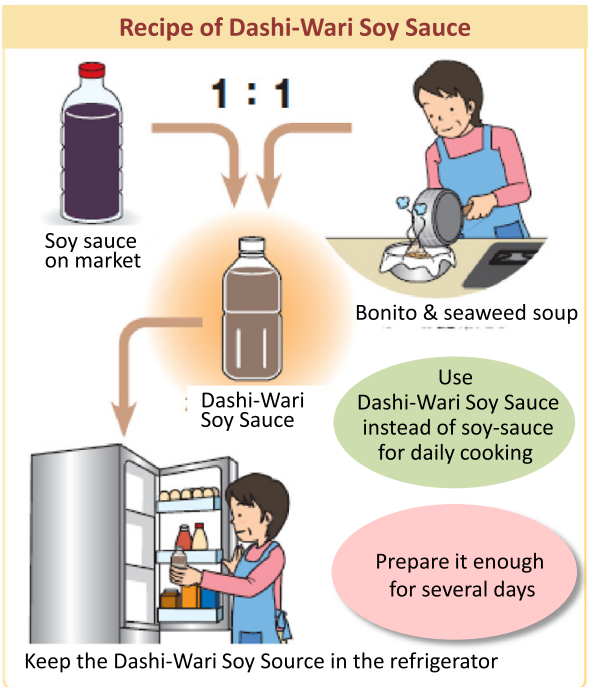

Fig. 3 Tips for salt restriction Use other than soy-source

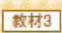

外食の塩分に注意! 塩分の多い料理はなに？

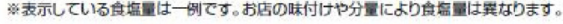

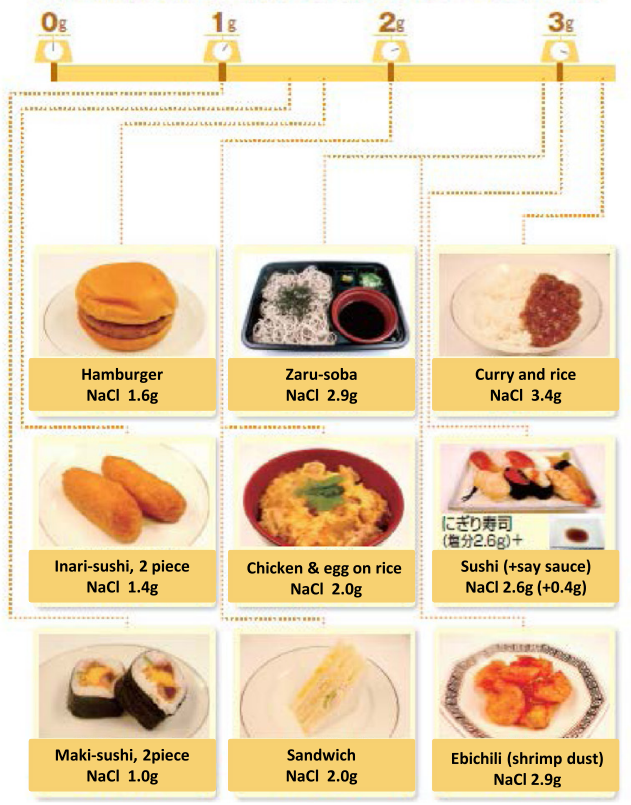

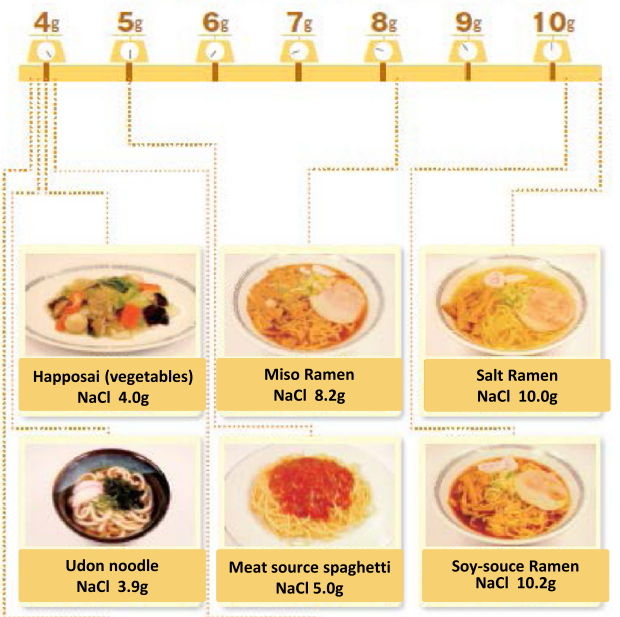
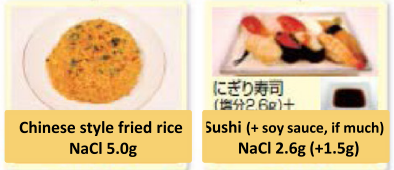

Fig. 4 Examples of salty foods at restaurants. (All figures are cited from "Manual for CKD life and dietary guidance manual for physicians and co-medical staffs; edited by the Japanese Society of Nephrology". Sample Legends: Sample 1. A sample of breakfast. Sample 2. A sample of lunch. Sample 3. A sample of dinner. Sample 4. A sample of balanced diet. (All cited from "Manual for CKD life and dietary guidance manual for physicians and co-medical staffs; edited by the Japanese Society of Nephrology") 
containing nitrogen. Protein (amino acids) is used to construct body protein and also used for energy production. Water and nitrogen compounds are excreted from kidney. Nitrogenous compounds will retain in the blood as kidney function deteriorates resulting uremic symptoms such as nausea, vomiting, anorexia, and anemia. Electrolyteimbalance such as hyperkalemia, hyperphosphatemia, and metabolic acidosis may appear in CKD stage 3 patients. To prevent such symptoms, protein restriction is indicated timely in accordance with remaining kidney function to prevent complications and also retard the progression of CKD.

2. Quality of protein Human body is constructed by protein such as elastin, collagen, hemoglobin, enzymes, and hormones. Essential amino acid such as leucine, isoleucine, valine, lysine, tryptophan, phenylalanine, threonine, methionine, histidine should be supplied as human cannot synthesize them. Foods with high content of essential amino acid expressed as high amino acid score is regarded as good quality protein food staff. Generally, animal meats are high amino acid score, but not so high in vegetables including soybean products (Table 3 ).

If protein intake is over $60 \mathrm{~g} /$ day, deficiency of essential amino acid is rarely occur. However, in

Table 3 Amino-acid score in common food in Japan(1973 FAO/ $\mathrm{WHO}$ ) (Cited with permission from the Japanese Society of Nephrology)

\begin{tabular}{ll}
\hline Food & Amino-acid score \\
\hline Salmon & 100 \\
Saury & 100 \\
Mackerel & 100 \\
Pork, Sirloin & 100 \\
Beef & 100 \\
Chicken, Round & 100 \\
Milk & 100 \\
Chicken Egg & 100 \\
Polished Rice & 65 \\
Soba & 65 \\
Sweet Potato & 88 \\
Potato & 68 \\
Soybean & 86 \\
Fermented Soybean (Natto) & 84 \\
Okura & 57 \\
Green Beans & 68 \\
Turnip & 45 \\
Asparagus & 68 \\
\hline
\end{tabular}

Table 4 Nutrient content in food common in Japan, expressed grams of food): Food Samples for protein restriction, adjusted to body size (Cited with permission from the Japanese Society of Nephrology)

\begin{tabular}{lllll}
\hline Height, cm & 174 & 157 & 152 & 148 \\
Energy, kcal/day & 2000 & 1800 & 1600 & 1400 \\
Protein, g/day & 55 & 45 & 40 & 35 \\
Rice, & 540 & 480 & 390 & 330 \\
Egg & 50 & 25 & 25 & 25 \\
Meat & 60 & 60 & 50 & 45 \\
Fish & 60 & 60 & 50 & 45 \\
Soybeans & 20 & 20 & 20 & 0 \\
Milk Products & 120 & 90 & 90 & 90 \\
Vegetables & 300 & 300 & 300 & 300 \\
Potato & 100 & 100 & 100 & 100 \\
Fruits & 120 & 120 & 120 & 120 \\
Sugar/sweets & 20 & 20 & 20 & 20 \\
Harusame (Gelatin Noodles) & 25 & 25 & 25 & 25 \\
Oils & 25 & 25 & 25 & 25 \\
Energy Additive, kcal & 100 & 100 & 100 & 100 \\
\hline
\end{tabular}

Three meals a day. Energy Additive; ex) soft-drinks containing carbohydrate $250 \mathrm{ml} \div 100 \mathrm{kcal}$

case of protein restriction, insufficient intake of essential amino acid and energy may occur, therefore careful monitoring is recommended to prevent protein-energy wasting (PEW). CKD patients with stage $3 \mathrm{~b}$ to 5 should be managed with trained dietician and nephrologist.

3. Lipid intake

Lipid intake should be 20 to $25 \%$ of the total energy intake. N-3 poly-unsaturated fatty acid is recommended for preventing atherosclerosis.

\section{A Sample of Breakfast}

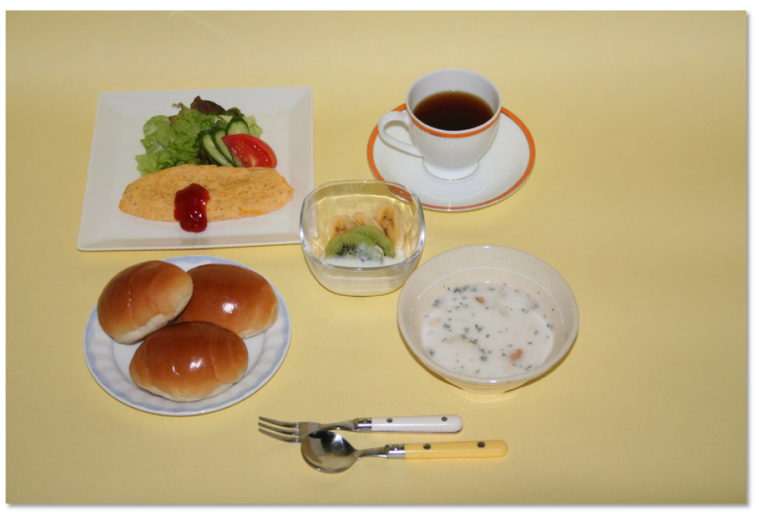

Sample 1 A sample of breakfast 


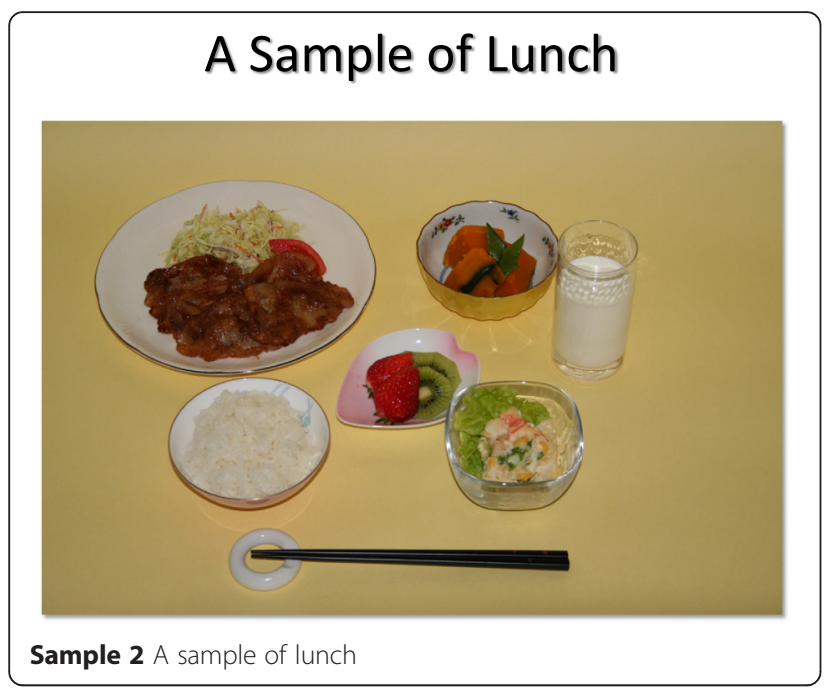

4. Energy intake

While practicing protein restriction, adequate energy intake should be maintained. Too strict protein restriction may result energy intake deficiency. In particular patients with CKD stage 4 to 5 . When energy intake is not sufficient, ingested protein is used for energy, but not for protein construction, resulting muscle and/or wasting. In patients with CKD stage $3 \mathrm{~b}$ to 5 , protein restriction of less than $0.8 \mathrm{~g} / \mathrm{kg} /$ day should be performed with guidance of special medical team.

5. Practical Guide (Table 4)

Patients are instructed to adhere protein restriction by using learning tools to estimate amount of protein, amino acid score, and salt. (Sample 1, 2, 3 and 4).

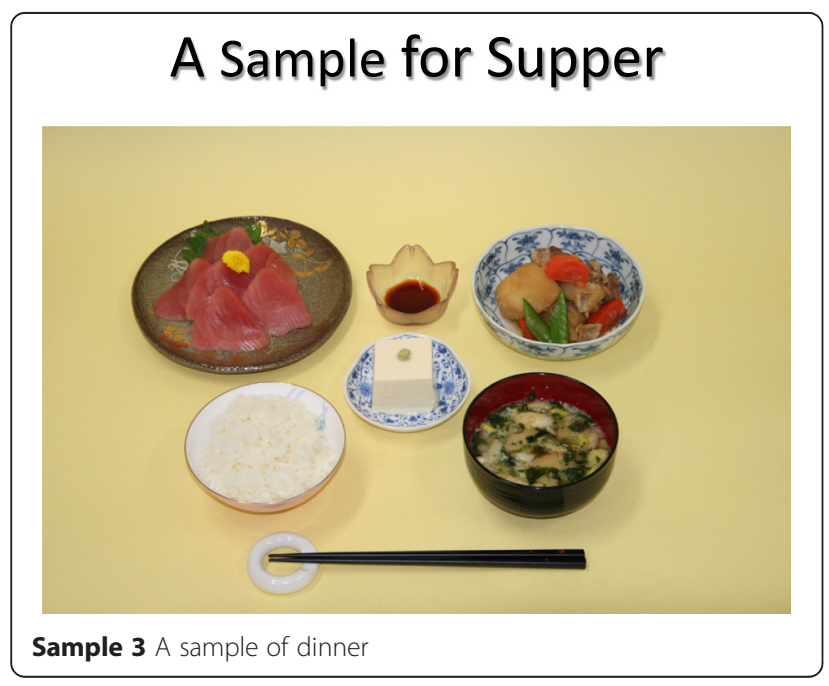

\section{A Sample of Balanced Diet}

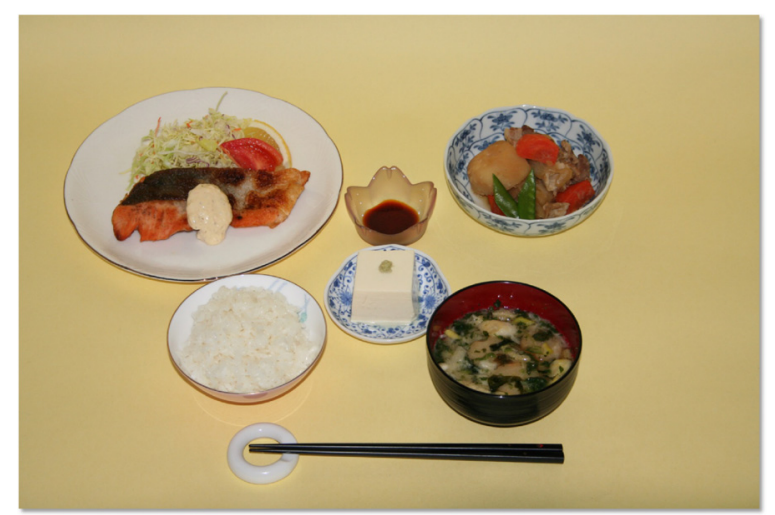

Sample 4 A sample of balanced diet (All cited from "Manual for CKD life and dietary guidance manual for physicians and co-medical staffs; edited by the Japanese Society of Nephrology")

\section{Summary}

We have done a strategic outcome study for chronic kidney disease: Frontier of Renal Outcome Modifications in Japan (FROM-J study) [4]. Management of CKD requires multi-disciplinary involvement. In this study, we prospectively observed the effects of intervention from dietitians and supportive care in CKD patients in addition to usual care recommended by Japanese Society of Nephrology [5]. Through this study, we published practical guidebook with full involvement from dietitian's society [2,3].

\section{Acknowledgements \\ Not applicable.}

\section{Funding}

This study was supported in part by a Grant-in-Aid for Research on Advanced Chronic Kidney Disease (REACH-J). Practical Research Project for Renal Diseases from Japan Agency for Medical Research and development, AMED.

\section{Availability of data and materials}

Not applicable.

\section{Authors' contributions}

Both authors contributed equally to the manuscript.

\section{Competing interests}

The authors declare that they have no competing interests.

\section{Consent for publication}

Not applicable.

\section{Ethics approval and consent to participate Not applicable.}

\section{Author details}

${ }^{1}$ Clinical Research Support Center, Tomishiro Central Hospital, Tomigusuku, Okinawa, Japan. ${ }^{2}$ Department of Nephrology, Faculty of Medicine, University of Tsukuba, Tsukuba, Ibaraki, Japan. ${ }^{3}$ Division of Nephrology, 1-1-1 Tennodai, Tsukuba, Ibaraki 305-8577, Japan. 


\section{References}

1. Yamagata K, Yagisawa T, Nakai S, Nakayama M, Imai E, Hattori M, Iseki K, Akiba T. Prevalence and incidence of chronic kidney disease stage G5 in Japan. Clin Exp Nephrol. 2015;19:54-64.

2. Manual of diet and lifestyle modification for CKD patients: for physicians and co-medical staffs. Edited by the Japanese Society of Nephrology (in Japanese). 2015

3. Manual of diet and lifestyle modification for CKD patients: Practical guide for dietary guidance. Edited by the Japanese Society of Nephrology (in Japanese). 2015

4. Yamagata K, Makino H, Akizawa T, Iseki K, Itoh S, Kimura K, Koya D, Narita I, Mitarai T, Miyazaki M, Tsubakihara Y, Watanabe T, Wada T, Sakai O. Advisory Committee for FROM-J. Design and methods of a strategic outcome study for chronic kidney disease: Frontier of Renal Outcome Modifications in Japan. Clin Exp Nephrol. 2010;14:144-51.

5. Practice Guide for CKD (2009, in Japanese). www.jsn.or.jp

Submit your next manuscript to BioMed Central and we will help you at every step:

- We accept pre-submission inquiries

- Our selector tool helps you to find the most relevant journal

- We provide round the clock customer support

- Convenient online submission

- Thorough peer review

- Inclusion in PubMed and all major indexing services

- Maximum visibility for your research

Submit your manuscript at www.biomedcentral.com/submit
Biomed Central 